\title{
'We Are Not As Bad as you Think we Are': Dealing with Diversity and Self-Exclusion in a Youth Football Club
}

\author{
Harrison Esam Awuh ${ }^{1}$ (D) Floor Spijkers $^{2}$
}

Received: 7 August 2019 / Accepted: 13 November 2019/Published online: 10 December 2019

(C) The Author(s) 2019

\begin{abstract}
Few studies have considered the capacity of place to facilitate or inhibit supportive responses to diversity. In this paper, we explore this capacity of place through an ethnographic case study of responses to diversity in a football club based in Antwerp, Belgium. Over a three year period we assessed the effects of three separate placedbased initiatives by the football club to promote inclusion of native Belgians in a football club that has become predominantly composed of people with migrant backgrounds. This paper demonstrates that initiatives which were based in places with normative values which promote diversity, acceptance and mutual respect delivered more positive outcomes for inclusion of native Belgians than in places without such norms and values.
\end{abstract}

Keywords Place $\cdot$ Ethno-cultural diversity $\cdot$ Encounter $\cdot$ Exclusion $\cdot$ Football $\cdot$ Belgium

\section{Introduction}

A growing number of big cities in Western Europe and North America are so called 'majority-minority cities'; the majority of people belonging to an ethnic or racial minority group (Crul 2016). Consequently, it is becoming increasingly important to understand how we live together in diversity. Intercultural relations are 'one of the main

Harrison Esam Awuh

h.e.awuh@asc.leidenuniv.nl

Floor Spijkers

floor.spijkers@kuleuven.be

1 African Studies Centre Leiden, Faculty of Social Sciences, Leiden University, Pieter de la Courtgebouw, Wassenaarseweg 52, 2333 AK Leiden, Netherlands

2 Division of Geography \& Tourism, GEO-Instituut, KU Leuven, Celestijnenlaan 200E - bus 2409, B-3001 Leuven, Heverlee, Belgium 
contemporary issues to be addressed by researchers, policy-makers, institutions, communities, families and individuals' (Berry 2013 page 1123). Within this domain of intercultural relations, 'geography matters fundamentally' as understanding the complexity of diversity requires an examination of different places, scales and conditions (Berg and Sigona 2013, page 352). Intercultural contact is not only situated in a particular place. The place also influences the experiences and outcomes of the contact (Clayton 2009: Askins 2015). In the emerging field of geographies of encounter, scholars investigate how encounters in everyday places of diversity can contribute to better intercultural relations. A particular interest is taken in contact that changes, challenges and nuances attitudes towards cultural others (Valentine 2008; Leitner 2012; Askins 2016; Gawlewicz 2016). Key to this strand of research is the focus on the spatiality of encounters, through understanding how encounters are influenced by place, setting, social and political context (Askins 2015). Although numerous places have been scrutinized in relation to everyday contact in diversity, the encounters tend to be the subject of investigation and relatively little attention has been paid to the influence of spatial elements (Mayblin et al. 2015).

Over the years, places have been categorized by scholars in different manners, based on factors such as opportunities for contact, types of contact, or rights of access. Places do not only host various types of interactions, they also vary in terms of how people present themselves (Goffman 1963). The distinction between public and private places dominated for a long time. Whereas public places are open in access, and predominantly host encounters between strangers, private places are highly controlled in terms of access and tend to be characterized by intimate relationships. In addition, the pressure to interact with one another tends to be relatively low in public places and high in private places (Feld 1981). Lofland (1989) added a third type of place to the distinction between public and private - parochial places. These so called parochial places host regular and repeated interactions between acquaintances. Parochial places where further subdivided by Loopmans (2002) who distinguished between semi-public and institutional places. In semi-public places, access is informally regulated, whereas in institutional places access is formally regulated. He analysed contact dynamics in private, public, semi-public and institutional places and found that public and private places were predominantly used for maintaining contact. New contacts were made at semi-public places if people were regularly present, but were most often established in institutional places (Loopmans 2002). More recently, Piekut and Valentine (2017) combined empirical material and existing literatures to distinguish different places based on their role in the relation between contact and attitude change. Their categories include private, public, institutional, socialization and consumption places. They argue that contact opportunities are great in public places, but provide little opportunity to change attitudes due to the fleeting nature of interactions. Therefore, they see more potential in the other types of places in which repeated encounters (consumption places), regulation of interaction (institutional places) or shared goals and interests (socialization places) can nurture personal interactions and challenge attitudes. As interactions in private places tend to be between people with close ties, there is a high potential for attitudes (Piekut and Valentine 2017).

Public places have received a lot of attention in the geographies of encounter literature, whereas places such as the home, the workplace or leisure places are largely underexplored (Gawlewicz 2016). There is a need to grow understanding of contact in 
what Amin (2002) called 'micropublics', such as sports clubs, schools or other places of association to understand how 'engagement with strangers in a common activity disrupts easy labelling of the stranger as enemy and initiates new attachments' (Amin 2002, page 970).

In addition to place, contact is of particular interest in this paper. In the literature as well as in practice contact is often assumed to improve intercultural relations. This belief is rooted in contact theory, originally formulated as an hypothesis by Allport (1954). Allport saw plenty of examples of negative intercultural relations and aimed to identify factors which would contribute to positive contact outcomes. He hypothesised that prejudice would be lowered by contact, if the people in the contact situation have equal status and work towards a common goal. This would be enhanced under the condition of institutional support, and the perception of a common humanity (Allport 1954). Although such an assertion goes against the popular saying that 'familiarity breeds contempt', the contact hypothesis is now established as one of the most effective strategies in promoting intergroup relations (Dovidio et al. 2010). The hypothesis has inspired hundreds of studies over the years, and its popularity is rapidly increasing in the literature (Pettigrew et al. 2011). A meta-analysis showed that in the vast majority of contact studies, the hypothesis was confirmed and the conditions set by Allport where facilitating rather than crucial (Pettigrew and Tropp 2006). Given the overwhelming evidence that contact indeed lowers prejudice, the hypothesis is now considered a theory (Hewstone and Swart 2011).

Whether or not contact takes place largely depends on chances and choices (Spijkers 2019). In terms of chances, places need to be diverse to allow for intercultural contact. Without a chance to meet, people may be willing to have intercultural contact, but the contact can not materialize. In addition, the higher the chance to meet someone interculturally, the more likely contact will follow. Chance is thus both a prerequisite and a facilitator of intercultural contact. When there is the chance to meet, the second precondition for intercultural contact to materialize becomes choice, which could be divided into a positive versus a negative choice (the choice to interact versus the choice to avoid). The degree of choice concerning who to interact with is dependent on factors such as the place of contact, the amount of people present, and the reason for contact. The contact hypothesis sets the scene (provides ideal conditions) for people to interact but it is the choice of the people to interact or not. We argue that chances for ethno-cultural majority-minority contact need to be created and the choices people make are shaped by the places in which the interactions take place.

In order to understand how places could influence the choices people make to interact with the other or not, we analyse three outreach initiatives of a youth football club in Antwerp, Belgium. These initiatives were set up in different places in the city and aimed at stimulating intercultural interaction, as well as drawing more affluent and native white Belgians to the club. We hypothesise that place will play a crucial role in determining outcomes of the intergroup contact initiatives. The aim of this paper is to understand how contact initiatives aimed at stimulating minority-majority interaction and changing attitudes are influenced by place. We analyse contact initiatives in institutional places versus public space to scrutinize place-based dynamics which facilitate or hinder the success of the initiatives. 


\subsection{The Case}

Sports clubs have been known to be the focus of community life by assisting in the formation of social networks that influence information flows and are inclusive of newly arrived immigrant groups and minority groups (Frost et al. 2013; Nichols et al. 2013; Jeanes et al. 2018). The Council of Europe for instance, recognizes promoting sports as a means of improving the quality of life, facilitating social integration and contributing to social cohesion (Council of the European Union 2010). Also, as far back as 2004, at least 20 countries in Europe were involved in projects which promote multicultural understanding through sports (Amara et al. 2005). Poverty, long-term unemployment, incomplete education and other social problems often lead to an uneasy negative social climate. The effect of such a negative social climate could be that affected groups withdraw from society (Social Exclusion Unit 2001), or are excluded by other groups in society. Sports clubs could deliver a solution to this problem by diminishing exclusion through the development of collective efficacy - a sense of confidence that a diverse group is capable of living and working together (Gibson 1999; Sampson 2006; Tasa et al. 2007; Spaaij 2012). They can create networks that bridge social barriers and open opportunities for participation by diverse groups of people (Tonts 2005).

As mentioned before, the football club in this study is based in the city of Antwerp, Belgium. Antwerp is the second largest city in Belgium and has a population of about 524,501 inhabitants as of 2018 of which close to half have a migrant background (Stad Antwerpen 2019). The city is home to one of Europe's largest ports, lies in the highly urbanized north-west European core area between London, Paris and the Ruhr. Antwerp has a particularly large medieval core of about 10 square $\mathrm{km}$ and an inner ring of densely built up, nineteenth-century working-class neighbourhoods (Loopmans 2008). This medieval core is distinct from peripheral locations outside the inner ring (the old city wall). The city is made up of nine districts: Antwerp, Borgerhout, Merksem, Berchem, Berendrecht-ZandvlietLillo, Ekeren, Wilrijk, Hoboken and Deurne. The football club is active in four neighbourhoods. The material presented in this paper is collected at the branch in one of the most deprived neighbourhoods in the city. Driven by his own personal experiences, the club president reorganized the club with a commitment to work for the underprivileged youth. This reorientation of the club consists of a large number of initiatives aimed at providing opportunities, fulfilling a role in society and the development of an effect that goes beyond football. With the new orientation, the club seeks to have an impact on the social development of their players and promote solidarity in diversity.

Concerning ethnic diversity at the club, although there are 20 different nationalities represented at the club's branch under study, of the 183 players, 146 have Belgian nationality. This high representation of youths with Belgian nationality is because most of the children are second generation migrants - born in Belgium and adopting Belgian nationality. In order to shed more light on the ethnic diversity of the club in a manner which goes beyond nationalities, Spijkers and Moris (2016) use the method of surname identification and tagging of the players. They distinguished between Belgian sounding and non-Belgian sounding names. This revealed that about 170 out of the 183 players in the club had a migrant background. Although they recognize that this is a potentially faulty method, it provides a glimpse of diversity in ethnic-cultural backgrounds, which cannot be derived from the citizenship of the players and their families. This method is 
often used in companies, including De Lijn (Flanders bus company) - as evidenced by the retrospective DieGem research there (Spijkers and Moris 2016), by the Flemish Employment and Vocational Training Service - VDAB (Gevers et al. 2004) and in the Flemish city monitors (Spijkers and Moris 2015).

The cultural diversity at the club with a marked underrepresentation of youths with non-immigrant backgrounds and the lack of economic diversity based on the family incomes pose serious challenges for the club. Firstly, the image of the club as, 'a club for foreigners' because of the overrepresentation of youths with migrant backgrounds often carries a negative connotation - a form of racism and xenophobia. On away games the players are often confronted with several forms or racism from opposing teams especially teams from suburban Antwerp with more conservative communities and views. This racist behaviour is often displayed by mainly the parents of their opponents. Addressing racism is a huge challenge, not only because of the racist attitudes of many other clubs, but also because it is often ignored and denied in the wider football world in Belgium (even at the level of the national football association). Racist incidents are often dismissed and are not mentioned in official reports. Paul Beloy, one of the first black players featuring in the Belgian League, believes not much has changed over the years concerning racism in Belgium especially for youngsters in football (Kunti 2016). He said, 'everywhere they go, they face racism - it's the black team playing against the white team - but these kids are just six, seven or eight years old' (Beloy in Kunti 2016).

\section{Methodology}

\subsection{Rationale for the Project}

The initiative to promote a diversity atmosphere characterized by more inclusion of Belgians with a non-immigrant background had several rationales. Firstly, the strong social aim of the club leads to the wish to have a representation of everyone on society. A clear underrepresentation of white Belgian players did not match the neighbourhood demographic. Secondly, the management of the club unanimously agreed to adopt strategies which can promote the inclusion of more Belgians with a non-immigrant background in the club in order to combat the stigmas which come with being regarded as 'a club for foreigners'. The final motivation for this drive to attract more youths of non-immigrant background was that generally there youths often come from relatively more affluent families. Ethno-cultural diversity and poverty are strongly related in Antwerp, as poverty is relatively often faced by people with migrant backgrounds (Oosterlynck et al. 2017). The inclusion of this demographic group of white affluent youths in the club could help in overcoming some of the financial burdens from the overrepresentation of youths from deprived families. The authors of this paper were tasked with assisting the club staff in carrying out an action research project to promote the values of the club outside the club and to attract more white Belgians to the club. We executed three different initiatives which were targeted towards stimulating contact through football between youths from different ethno-cultural and socio-economic backgrounds, as well as lowering the threshold for native white Belgian youths and youths from more affluent families to join the club. The analysed initiatives include; recreation football, Pleintjes and the school challenge. 
Recreation football: This initiative takes place at the football grounds of the club. Its aim is to provide a stepping stone for non-immigrant youths and their parents to first get to know the club before deciding to join the club or not. A group of players from some schools with predominantly non-immigrant youths were initially invited to start the programme. Over the years, membership in this group has been sustained by viva voce invitations. In the recreation football, the players (6 to 13 years of age) train only once a week. The youths do not play any games on weekends and their parents are not under any obligation to carry out any extra functions at the club. This set up suits parents who might be reluctant to initially get deeply involved with the club and who might prefer a gradual immersion into the club (lowering of the threshold). The limited level of commitment in the recreation football also suits families whose children often have a range of other sports planned over the days of the week - meaning they cannot easily over commit to the normal three days a week in the regular football season. At the end of the season, recreation football players and parents are invited to join the regular football set-up at the club or are given the flexibility of joining the regular club set-up whenever they feel comfortable with making that next step.

Pleintjes: This initiative entails a football tournament set up in various neighbourhoods. At a meeting between the staff of the club on the 23rd of July 2016, neighbourhoods to include in the tournament were identified. Neighbourhoods were selected based on socio-economic factors such as ethno-racial composition and deprivation index. ${ }^{1}$ Both neighbourhoods with lower deprivation indexes and less youths with migrant backgrounds and neighbourhoods with high deprivation indexes and more youths with migrant backgrounds were included. In total six neighbourhoods were selected for the football tournament of which one was later dropped as a site for the games because of the absence of public space suitable for small-sided football games. The aim of this outreach activity was to take solidarity, diversity and football from the premises of the football club to the neighbourhoods (See Fig. 1). The objective was that through solidarity in the football programme, youths of non-immigrant background living in well-to-do neighbourhoods might have a greater predisposition to join the football club. Also, passers-by were invited to join as the events unfolded. Players were allowed to pick their own teams. In order to further increase contact between youths from different neighbourhoods, the teams which qualified for the finals of the tournament in each neighbourhood were transported by minibus the next day to play against other teams from and in different neighbourhoods.

School challenge: The school challenge was a lunchtime football tournament on the grounds of a local primary school. The aim of the programme was to introduce the club to the majority (over 60\%) non-immigrant school children and their families at the school and to subsequently invite them to join the club. The tournament was organized over the last 2 weeks of March 2017; Thursday 23/3, Friday 24/3, Thursday 30/3 and Friday 31/3. All the games were played on the school's playground during the lunch break (12:30 pm - 13:30 pm). On every day of play, particular school grades (based on school age groups) had the chance to play. On the final day, the best teams from all the

\footnotetext{
${ }^{1}$ Deprivation index is an indicator of the chance that youths in that neighbourhood grow up in poverty. Poverty plays a major role in social exclusion from sport and many other domains of people's lives (Collins and Kay 2003; Collins and Haudenhuyse 2015). Poverty limits peoples' life choices and excludes them from many leisure possibilities and money is listed as the most significant constraint (Collins and Haudenhuyse 2015).
} 


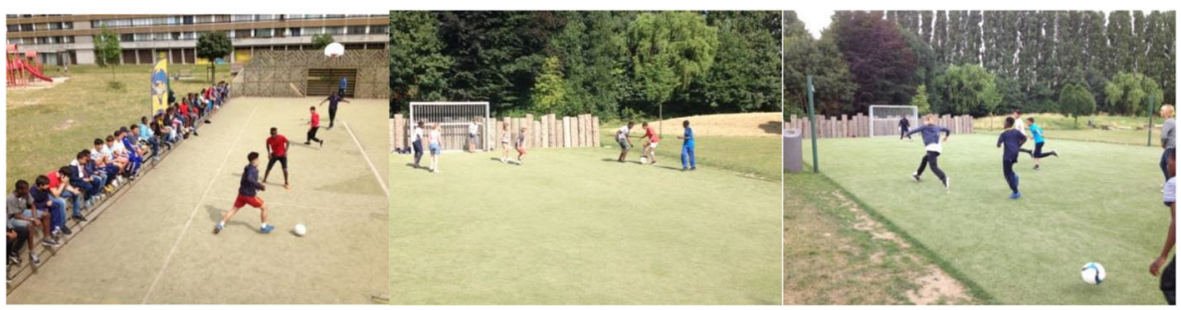

Fig. 1 Pleintjes in two neighbourhoods

age grades played the final games to determine the school grade winners. A total of 140 pupils at the school participated in the lunchtime football programme. At the end of the programme, invitations were sent out to the parents encouraging them to send their children to the football club.

\subsection{Methods}

We utilized a mainly qualitative approach for data collection in this study - semistructured interviews and participant observation.

\subsubsection{Participant Observation}

A co-author of this paper was embedded in the club for three years as a coach and the other co-author conducted research at the club prior to this project. The former's background as an ex-footballer and qualified coach eased acceptance/entry into the club. This provided in-depth knowledge of the club from a participant observer perspective. Participant observation is mainly used in ethnographic and social studies and is a method that enables researchers to 'learn about the activities of the people under study in the natural setting through observing and participating in those activities' (Kawulich 2005: page 2). Participant observation was particularly useful in this research to provide context, to enable the participant to familiarize themselves with the researcher and to adjust the interviews conducted in the later stage to the local context. Furthermore, participant observation allowed for observations to try to understand experiences and other aspects in life at the club and at the outreach initiatives that were expressed by the participants. Observation and informal conversations in the capacity of a football coach also contributed to discovering underlying dynamics that will not be easily mentioned in the 'formal' interviews, thereby adding new information. The main limitation of this method is that the observation is conducted by a biased human. Therefore it is crucial to understand that the researcher's positionality could likely influence informal talks, observations, analysis and interpretations. For instance, the positionality of the co-author as a sub-Saharan African (migrant) made it easier to connect with the youths with migrant backgrounds. The co-author positioned himself as one of them and that eased communication with the immigrant youths because they had a lot of things in common and there was the feeling that they saw the researcher mainly as a fellow immigrant, rather than an authority. Despite the disadvantages of this insider perspective and risk of positionality bias, (participant) observation remains a useful method that has strengthened the development of the interviews and surveys and vice versa (Kawulich 2005). 


\subsubsection{Semi-Structured Interviews}

Qualitative interviews were conducted with the youths $(n=30)$ from whom we could obtain verbal parental consent at Pleintjes. Each interview with the youths was brief lasting approximately 10 min because it was challenging to keep the youths focused for a longer period of time (particularly while the football games were going on). Each youth to be interviewed was pulled away from the others in order to prevent responses being influence by other youths following the interviews. The following questions were asked to the youths amongst others:

- Where do you live?

- How did you hear about Pleintjes?

- What do you like about the Pleintjes? What do you not like about Pleintjes?

- Have you played football in other neighbourhoods in the course of Pleintjes? What have you learned from playing football in other neighbourhoods? Can you tell me which other neighbourhoods you have been to?

- Have you made any new friends in the course of Pleintjes? If yes, how many new friends have you made? Can you name some of them?

We also conducted extended semi-structured interviews with club staff and volunteers $(n=4)$, and the parents of four white Belgian youths who joined the club through one of the initiatives. The club staff were asked the following questions amongst others:

- What were the objectives of the club in organizing these initiatives?

- How do these objectives relate to the general norms and values of the club?

- Which of the objectives of the club were achieved through the organization of the outreach initiatives and why? Which objectives were not achieved and why?

- What were the major challenges in the organization and execution of the outreach initiatives? What attempts were made to mitigate these problems?

Each interview with an adult lasted for approximately one hour. To analyse the qualitative data, this research used content analysis. Interviews were transcribed and coded according to important themes and then analysed based on these themes.

\subsubsection{Literature Review}

Along with these traditional research methods, a large number of documents were analysed by one of the authors including the youth education plan, mission statements and articles of the football club in the media. Findings were discussed amongst the authors, enhancing rigour through credibility and dependability.

\subsubsection{Ethics}

We started and ended each interview and with a note on consent and would constantly remind the participants in interviews that they could always skip a question or stop the interview if they felt uncomfortable. We admit that it will have been ideal to conduct quantitative surveys to gather a broader amount of data in order to compare larger 
groups of participants. However, as stated before, this was challenging due to the difficulties in obtaining consent from the parents of a large group of youths. Nevertheless, verbal consent was obtained from the parents of 30 youths. Such consent was obtained either at the beginning of the training sessions or outreach initiatives (drop-off time) or at the end (pick-up time). Most parent did not stay to follow the football training or initiatives.

\section{Findings}

We explored two types of places of contact (institutional in comparison to a public place), analysed how entry and intergroup contact was regulated within them and the norms and values attached to each place. In addition, whether or not youths join the club is not only related to positive contact experiences with other members, but also with the image they have of the club itself. This will be discussed at the end of this findings section.

\subsection{Institutional Places}

Institutional places are those where both access and interaction are 'managed' by an actor who has territorial control over that particular place and have strong potential in fostering intercultural relations (Spijkers and Loopmans 2018). Interactions in the football club's grounds (recreation football) and in the school (school challenge) fall within the realm of institutional places. Access to the football field or the school playground where the games took place was based on membership or belonging to the school and a commitment to be regularly present. Access to the school was regulated by the need to register and pay school fees. Access to the football fields at the club were regulated by the obligation to register and pay a yearly fee. In the recreation football, the players are obliged to train once a week - on Wednesdays from $2 \mathrm{pm}$ till 3:30 pm - over the full eight months of the football season. The participation fee is 60 Euros per football season and parents are responsible for purchasing the football gear and obliged to ensure their children participate. This obligation to participate ensured regularity of contact.

According to Allport's 'contact hypothesis' (Allport 1954; Pettigrew and Tropp 2006), facilitating conditions which could promote the development of more harmonious conditions between groups include amongst others, the influence of institutional support. Institutional places have shaped norms and values which are considered appropriate. The real-world value of institutional norms and values is that they give critical cues which allow us to organize our behaviour appropriately. With reference to Talcott Parsons' 1956 institutional theory (Parsons 1990; Tolbert and Zucker 1999), institutions such as schools or sports clubs sanction human behaviour. Parsons stresses the subjective dimensions of institutions whereby individual actors internalize shared norms and values so that they become the basis for the individual's action. Parsons views an institutions as 'a system of norms defining what the relations of individuals or organisations ought to be' (Parsons 1990; page 327). This normative view of institutions is re-echoed by Emile Durkheim who defined institutions as products of joint activity and association, the effect of which is to fix and institute outside us certain 
subjective ways of acting and judging (Durkheim 2005). These wider normative structures within society serve to legitimate the existence of organizations and the main functional patterns of operation which are necessary to implement the values for which the organizations stand for (Scott 2013). For instance, schools receive legitimacy from society. This legitimacy connects their goals to the cultural values of the society and to the degree to which they conform in their structures and procedures to establish patterns of operation. Also, value systems are stratified within society and institutions serving more esteemed values are thought to be more legitimate and are expected to receive a disproportionate share of societal resources (Parsons 1953; Scott 2013).

While some consequences of our actions occur as planned, others are heavily influenced by the contexts or environments in which they occur. Most significantly, and in relation to the case in this paper, intercultural interactions at the school and the football club are the results of actions which arise from commitments enforced by these institutions. These include education and sensitisation of the youths on the value of respect for one another no matter ethnic or racial backgrounds. A member of staff at the football club in relation to norms and values promoted by the club said:

We teach the kids to respect even the people who racially abuse them. They have to show they are not like the racists who abuse them. They should not respond in any manner which will prove the ill-conceived negative stereotypes the racists have of them right (Staff $\mathrm{A}$ ).

Professionals in these places such as the school and the football club governed by institutional norms, play an important role (Spijkers 2019). However, they remains largely absent in the literature on places of contact. This is possibly due to the predominant focus on places where professionals are either absent or only marginally present. Institutions do not just run themselves, they are driven by professionals. From their edited book on place-based solidarities in diversity, Oosterlynck et al. (2017) conclude that 'solidarities and institutions co-constitute each other in a mutually reinforcing way' (Oosterlynck et al. page 13). Professionals can facilitate and stimulate interaction, as well as influence the nature of interaction. Furthermore, professionals can influence the 'diversity climate'. Stemming from organizational literature, diversity climate refers to perceptions of diversity practices and policies, most notably in respect to social inclusion and fair treatment (Boehm et al. 2014). A positive diversity climate enhances both individual (psychological), social (better relations and less discrimination) organizational outcomes (Chrobot-Mason and Aramovich 2013; Boehm et al. 2014). Additionally, research shows that institutional places such as schools can transmit pro-diversity values such as empathy, anti-discrimination and respect, and stimulate a positive diversity climate through social norms (Ata et al. 2009; Hemming 2011).

We recognize the limitations of the assumption that structure simply constrains and enables action and that individuals are assumed to accept and follow social norms and values unquestioningly, without any real reflection or behavioural resistance based on their own particular personal interests. Nonetheless, crucial to our participants' experience of contact in structured institutional places is that it provides an opportunity to learn about other people (see also Spijkers and Loopmans 2018). In our case, the structure (through restricted access and obligation to conform to the norm and values of 
the places) led to relatively more positive intergroup contact outcomes in outreach activities at the school (school challenge) and the club (recreation football).

The recreation football initiative increased diversity in the club by increasing the representation of youths with a non-immigrant background in the club. During the 2015/2016 football season, there were 17 players - 11 of them of non-migrant background and 5 of migrant background. At the end of this season, of the six players who decided to join the club and play in the regular season, four of them were of nonimmigrant background. During the next season of the recreation football (2016/2017), there were 17 players again in the team - 12 of them were of non-immigrant background and 5 of immigrant background. During this season, there were five new players with a non-migrant background who joined the programme based on recommendations from their non-immigrant friends already on the programme. At the end of the football season in April 2017, six of the non-immigrant youths had decided to register at the club for the regular season 2017/2018 which began in August 2017. In the third season (2017/2018), there were 25 players in the recreation football programme. In this season, the number of new players with a non-immigrant background increased from 5 in the previous season to 11. Eleven new players with a nonimmigrant background added to six returning players from the previous season gave a total of 17 players with a non-immigrant background in a total of 25 players in the programme. Therefore, during the first two seasons, 10 players with non-immigrant background joined the club through the pathway of the recreation football. This comprises approximately $5 \%$ of the total population of the club.

The school challenge increased diversity in the club and contact between the club and the non-immigrant children and their families at the school. Before the initiative, the club had 14 players (all of them with migrant backgrounds) at the school. After the initiative, eight new players (6 with non-immigrant backgrounds) registered with the club. These new players were all under the age of $10-$ a group which was specifically targeted during the lunchtime programme with the handing out of flyers bearing information about the club and its activities. They were specifically targeted because of the more acute underrepresentation of non-migrant players in this age group relative to other age groups at the club. On their registration forms at the football club, the parents of the new players all highlighted the role of the school challenge in motivating them to join the club. The director of football at the club said, 'I think the school intervention was a success because some kids with a non-immigrant background from the school came to the club and registered after the intervention'.

\subsection{Public Place - The Park}

Public places are in principle accessible to all, and chances of encounters with people of different ethno-cultural origins is highest in these type of places (Wiesemann 2012; Piekut and Valentine 2017). However, encounters in public places tend to be limited to fleeting contact. Moreover, the lack of an obligation to interact in public places allows for selectivity in interaction. Stein et al. (2000) state that when it is primarily a voluntary decision who to interact with, people tend to choose others who are similar to them as captured in the proverb, 'birds of a feather flock together'. This phenomenon was already overserved ages ago by the ancient philosophers Plato and Artistotle (McPherson et al. 2001). In current literatures the tendency to prefer people similar 
to oneself is referred to as homophily in sociology and similarity-attraction effect in psychology (Schug and Lu 2015). Being similar can refer to any shared characteristic and sharing an ethno-cultural background has shown to be an important selection criteria in social networks (Fortuin et al. 2014). Strong divides are made in diverse societies based on race and ethnicity (McPherson et al. 2001).

A combination of the core group of the players in the Pleintjes being of migrant backgrounds, and the lack of institutional norms and values which oblige or enhance intergroup interaction led to Pleintjes attracting mostly youths with migrant backgrounds (See Fig. 2). Furthermore, none of the few non-immigrant youths who participated in Pleintjes ended up joining the club. However, Pleintjes led to increased and more positive interaction between youths with migrant backgrounds. Driven by homophily these youths chose to interact more with other immigrant youths than with the white Belgian youths. Out of 30 youths interviewed during and after the Pleintjes, 21 affirmed having made between one to five new friends in the course of the tournament, six made more than five new friends and three of them could not quantify the number of friends they made. We used surname identification in an effort to link the surname of the new friends mentioned to a possible country of origin. The term 'friends' was defined as people who they met beyond the football pitch and people with whom they exchanged contact details (Facebook, email or telephone numbers). The results indicated that there were no new intergroup friendships created during the Pleintjes. Youths with immigrant backgrounds made new friends with other youths with immigrant backgrounds.

Furthermore, although the presence of the club staff at the park events provided a degree of institutional regulation, such regulation could be perceived as temporal and limited because a public place like the park will not be permanently associated with a football club. In the case of the school and the football fields at the club, these are places which people habitually associate with certain institutions. The permanence of these institutional places legitimizes their acceptance and facilitates interaction between the people committing to this institution, which is absent in public. For instance, people will know for certain that for a long time certain places will be schools or football clubs and the permanence legitimizes the norms and values of such places. Alternatively, with a football programme in a public park (even when coordinated by an established institution), the feeling of permanence is absent. Parks as public places lack the structure with controlled access and repeated contact and legitimate norms and values which some people find reassuring. People associate a public park with lack of control

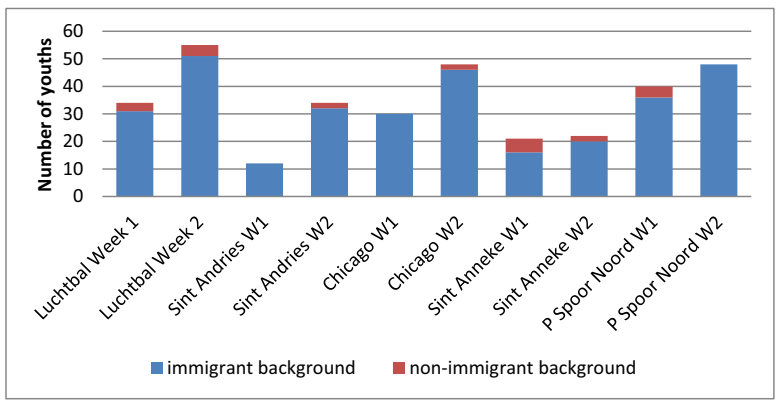

Fig. 2 Turnout and demographic composition of teams at the Pleintjes initiative 
(either in access or norms and values) and encounters in such places could more likely be inhibited by the choice people make to engage or not. For example, during the second week in one of the neighbourhoods, only one of the four players who participated in the first week was present. When the researcher asked the girl why her friends did not come with her a second time, she said, 'their parents forbade them from playing football in the park with "these" children'. This reflects their parents' possible view of the park as a place with no norms and values they can identify with. So, although in principle, the openness of a public park makes it an ideal realm for inter-group encounters, this ideal does not necessarily hold true since public space is socially constructed and reflects complex normative social standards between various groups. Therefore, the outcome of Pleintjes resulted in parallel lives and self-exclusion instead of the strengthening of inter-group contact and ties as intended. Non-immigrant residents in the neighbourhoods self-excluded by not participating in the initiative or not joining when invited to.

Also, structure and regulation are normative values which some members of the public will find more acceptable. The public park for example provides less of this structure and order due to its open access. Although Pleintjes was organized by a structured institution such as the football club, the lack of association of the public park in which it was hosted with structure and order seriously diminished the chances of success of the initiative. The director of football at the club believes the low turn-out of non-immigrant youths in non-immigrant neighbourhoods was because most families with non-immigrant backgrounds will prefer to send their children to structured football programmes with more discipline than to let them play in an unstructured football tournament in the neighbourhood square. Concerning the lack of structure, one member of staff pointed to medium of public communication concerning the Pleintjes initiative.

I said we have to make flyers to inform people about the Pleintjes. However, that didn't work out because my colleagues said we should just turn up in the park, blast the loud music and the youths will come. I think the lack of proper flyers which inform people about the Pleintjes revealed a lack of structure and professionalism. This lack of professionalism and structure is one of the main reason a lot of white youths did not participate in the Pleintjes. (club member of staff)

Structure also guarantees familiarity. Structure guarantees regularity of contact and through this, parents will more likely know or be familiar with who their children are playing with through the prolonged nature of the encounters. The institutions - the club and the school - facilitated this prolonged engagement. Players have to train and play together about two to four hours a week. At school, the youths spend approximately $30 \mathrm{~h}$ a week with each other. This prolonged engagement in an institutional setting facilitates opportunities for intercultural engagement more than the case with an outreach program in a public park which only lasts for only a couple of hours per week over a period of less than two months.

\subsection{The club's Image}

To some families, there is the negative association of the place (geographic location) of the football club with failure, bankruptcy and indiscipline. The club filled an empty 
spot in the neighbourhood left by a previous football club. This previous club went bankrupt after issues with financial mismanagement and increasing amounts of members from low income families. Some parents in the neighbourhood still have fresh memories about the previous club and its failure and lack faith that things are different at the current club. These parents are often Belgian middle-class who live in the neighbourhood but decide their children join clubs further away that have a better track record. As the financial mismanagement was less visible to parents than the big influx of children from migrant families, the multiculturalism of the club is associated with failure for some parents. A member of staff at the club said:

I saw this player I know who lives just down the road from here at a youth football tournament. I asked him which club he plays for and he said, Beveren. So, I asked why he will choose to go to Beveren - 11.4 kilometres away - when there is a football club just around the corner? He responded that, "my father said your club is a bad club". (Club member of staff)

It is up to the football club to stand the test of time and convince the sceptic nonimmigrant Belgians that the club is not the previous bankrupt club and that things are actually being done differently. A member of staff shared his optimism that this negative image of the club will slowly be erased as the club gets older in the neighbourhood. However, this is a point of view which clearly frustrates other people at the club. As one of them said:

I think over the last three years this club has done a lot in this neighbourhood in a bid to be viewed in a positive light. Now I think it is up to the people in the neighbourhood - meaning white Belgians - to seek to engage with the club. In short, we are tired of chasing them and begging them to see how good we are and how wrong their preconceptions about us are. The white Belgians know we are here and if they prefer to take their kids to other clubs in other neighbourhoods then it is their choice which we should respect (Staff SK).

Another observation is that the norms and values of the club as an institution are subjective and do not necessarily reflect the standard or acceptable norms and values expected of an institution by some segments of the population. This also provides a twist to the representation of schools and sports clubs as generally 'places of good behaviour'. People who do not appreciate the norms of an institution such as a sports club could actually avoid such places. We observed that one push factor at the club could be the representation of the club as a 'hip' club with loud music and graffiti (see Fig. 3) along with the perceived disregard for punctuality. These are values and norms which are incompatible with the norms and values of some non-immigrant families. For example, it was observed that late coming to training is common even amongst some coaches. This disregard for punctuality could dissuade a lot of mainstream nonimmigrant Belgians from sending their children to the club. Another concern is the graffiti covering the walls of the club rooms with the face of a Belgian national football star (who grew up in the neighbourhood). While the footballer is a popular player in Belgium, not ever parent will appreciate having his face in graffiti on the main buildings of a youth football club. A member of staff said: 


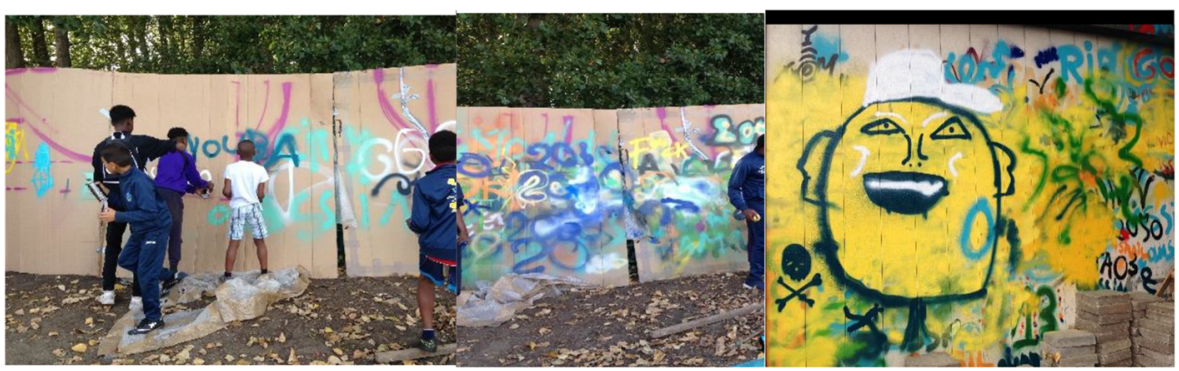

Fig. 3 Graffiti exercise at the football club

I don't think the graffiti on the walls here helps in the drive to attract white middle class Belgians. In my opinion, the graffiti looks cool to the youths but I am not sure their parents will equally appreciate it. The club is not a hipster club and while I don't have a problem with hipster style, I just feel that adopting this hipster image is not helping in attracting the mainstream white Belgians' (Staff X).

The same could apply to the loud music which was constantly played at the Pleintjes. While the music creates a fun atmosphere, there are some Belgians with non-immigrant background who found the noise completely inappropriate. 'The loud music and graffiti will possibly end up attracting mostly groups who do not see any problem with these. In most cases these will be the people with a migrant background'(respondent Y). Another respondent, a white middle aged Belgian lady added that, 'although I like the loud music and graffiti, I think generally when you play loud music and promote graffiti you tend to attract a certain demographic (young people with immigrant backgrounds)'.

A passer-by who was casually questioned on one of the Pleintjes days said:

The club wants to have a gangster image but that is not OK for many white Belgians. To me, they shout 'we are gangsters' too much. The music is a good idea but what I do not like is the kind of music they are playing. They play only rap music and a lot of white Belgians have a negative opinion on rap music. Personally I don't want anything to do with that kind of music and I won't like my kids to be associated with that kind of music. (a passer-by)

\section{Conclusion}

This paper reveals how place plays an important role in facilitating majority-minority contact. Generally, we found that the initiatives at the school and club grounds (institutional places) had more positive results in light of reaching out to white Belgians than the one in the park (public place). These positive results were both in terms of materialization of majority-minority contact and the amount of Belgian background children joining the club. The park initiative did enhance contact between youths with different ethno-cultural backgrounds, but not between those with and without a Belgian background. In addition, although some youths joined the club after the park initiative, 
none of these where white Belgian. This shows that the institutional initiatives were more successful in enhancing minority-majority interactions than the public initiative. The public initiative mainly attracted children similar to those already present at the club and failed to challenged negative perceptions of white Belgians.

The European Union and the Belgian government policies on integration of immigrants or people of immigrant backgrounds have long focused on migrants making an effort to integrate or efforts to help immigrants to integrate from the immigrant's perspective learning the language, finding a job and understanding the customs of the host country (see European Migration Network 2016). However, integrating immigrants (i.e. allowing them to participate in the host society at the same level as native groups), is a two-way process that involves two parties; the host society and the immigrants. There is the need for the two groups to work together to build a cohesive society and for the hosts to not regard the immigrants as 'those people' with the negative connotation which comes with that tag. Interactions can be facilitated by favourable places of encounter such as schools and football clubs which foster values of 'living together' and lower the threshold of establishing contact.

Acknowledgments We would like to thank Professor Maarten Loopmans (KU Leuven) for his expert advice and encouragement throughout this study. The study was partially funded by DIEGEM (Diversiteit in De Gemeenschap [Diversity in the Community]) Project, Belgium.

\section{Compliance with Ethical Standards}

Conflict of Interest On behalf of all authors, the corresponding author states that there is no conflict of interest.

Open Access This article is licensed under a Creative Commons Attribution 4.0 International License, which permits use, sharing, adaptation, distribution and reproduction in any medium or format, as long as you give appropriate credit to the original author(s) and the source, provide a link to the Creative Commons licence, and indicate if changes were made. The images or other third party material in this article are included in the article's Creative Commons licence, unless indicated otherwise in a credit line to the material. If material is not included in the article's Creative Commons licence and your intended use is not permitted by statutory regulation or exceeds the permitted use, you will need to obtain permission directly from the copyright holder. To view a copy of this licence, visit http://creativecommons.org/licenses/by/4.0/.

\section{References}

Allport, G. W. (1954). The nature of prejudice. Cambridge, Massachutes: Addison-Wesley Publishing Company. Amara, M., Aquilina, D., Argent, E., Betzer-Tayar, M., Coalter, F., Green, M., \& Taylor, J. (2005). The roles of sport and education in the social inclusion of asylum seekers and refugees: An evaluation of policy and practice in the $U K$. Loughborough: Institute of Sport and Leisure Policy, Loughborough University and Stirling University.

Amin, A. (2002). Ethnicity and the multicultural city: Living with diversity. Environment and Planning A, 34(6), 959-980.

Askins, K. (2015). Being together: Everyday geographies and the quiet politics of belonging. ACME: an International E-journal for Critical Geographies, 14(2), 461-469.

Askins, K. (2016). Emotional citizenry: Everyday geographies of befriending, belonging and intercultural encounter. Transactions of the Institute of British Geographers, 41(4), 515-527.

Ata, A., Bastian, B., \& Lusher, D. (2009). Intergroup contact in context: The mediating role of social norms and group-based perceptions on the contact-prejudice link. International Journal of Intercultural Relations, 33(6), 498-506.

Berg, M. L., \& Sigona, N. (2013). Ethnography, diversity and urban space. Identities, 20(4), 347-360. 
Berry, J. W. (2013). Research on multiculturalism in Canada. International Journal of Intercultural Relations, 37(6), 663-675.

Boehm, S. A., Dwertmann, D. J., Kunze, F., Michaelis, B., Parks, K. M., \& McDonald, D. P. (2014). Expanding insights on the diversity climate-performance link: The role of workgroup discrimination and group size. Human Resource Management, 53, 379-402.

Chrobot-Mason, D., \& Aramovich, N. P. (2013). The psychological benefits of creating an affirming climate for workplace diversity. Group and Organization Management, 38, 659-689.

Clayton, J. (2009). Thinking spatially: Towards an everyday understanding of inter-ethnic relations. Social \& Cultural Geography, 10(4), 481-498.

Collins, M., \& Haudenhuyse, R. (2015). Social exclusion and austerity policies in England: The role of sports in a new area of social polarisation and inequality? Social inclusion, 3(3), 5-18.

Collins, M., \& Kay, T. (2003). Sport and social exclusion. London: Routledge.

Council of the European Union. (2010) Conclusions of 18 November 2010 on the role of sport as a source and driver for active social inclusion (Official Journal 3.12.2010 C326/5-7). Brussels: Council of the European Union.

Crul, M. (2016). Super-diversity vs. assimilation: How complex diversity in majority-minority cities challenges the assumptions of assimilation. Journal of Ethnic and Migration Studies, 42(1), 54-68.

Dovidio, J. F., Hewstone, M., Glick, P., \& Esses, V. M. (2010). Prejudice, stereotyping and discrimination: Theoretical and empirical overview. In J. F. Dovidio, M. Hewstone, P. Glick, \& V. M. Esses (Eds.), The SAGE handbook of prejudice, stereotyping and discrimination (pp. 3-29). London: SAGE.

Durkheim, E. (2005). Suicide: A study in sociology. London: Routledge.

European Migration Network. (2016). Integration of beneficiaries of international protection into the labour market in Belgium. The European migration Network. Retrieved from https://emnbelgium. be/sites/default/files/publications/integration_of_beneficiaries_of_international_protection_into_the labour_market_in_belgium_final.pdf

Feld, S. L. (1981). The focused organization of social ties. American Journal of Sociology, 86(5), 1015-1035.

Fortuin, J., Van Geel, M., Ziberna, A., \& Vedder, P. (2014). Ethnic preferences in friendships and casual contacts between majority and minority children in the Netherlands. International Journal of Intercultural Relations, 41, 57-65.

Frost, L., Lightbody, M., \& Halabi, A. K. (2013). Expanding social inclusion in community sports organizations: Evidence from rural Australian football clubs. Journal of Sport Management, 27(6), 453-466.

Gawlewicz, A. (2016). Beyond openness and prejudice: The consequences of migrant encounters with difference. Environment and Planning A, 48(2), 256-272.

Gevers, A., Devisscher, S., Huys, R., Vanderbeken, W., Vandenbrande, T., \& Sels, L. (2004). Verkenning van en beleidsuitdagingen voor de Vlaamse arbeidsmarkt in de periode 2004-2010 [Exploration of and policy challenges for the Flemish labor market in the period 2004-2010]. Leuven/Brussel: Katholieke Universiteit Leuven. Hoger instituut voor de arbeid /Departement TEW / Idea Consult, 2004, page 244.

Gibson, C. B. (1999). Do they do what they believe they can? Group efficacy and group effectiveness across tasks and cultures. Academy of Management Journal, 42(2), 138-152.

Goffman, E. (1963). Behavior in public places: Notes on the social organization of gatherings. New York: The Free Press.

Hemming, P. J. (2011). Meaningful encounters? Religion and social cohesion in the English primary school. Social \& Cultural Geography, 12(01), 63-81.

Hewstone, M., \& Swart, H. (2011). Fifty-odd years of inter-group contact: From hypothesis to integrated theory. British Journal of Social Psychology, 50(3), 374-386.

Jeanes, R., Spaaij, R., Magee, J., Farquharson, K., Gorman, S., \& Lusher, D. (2018). 'Yes we are inclusive': Examining provision for young people with disabilities in community sport clubs. Sport Management Review, 21(1), 38-50.

Kawulich, B. B. (2005). Participant observation as a data collection method. Qualitative Social Research, 6(2), $1-28$.

Kunti, S. (2016) Ex-player Paul Beloy says racism is still an issue in Belgium. Retrieved from: http://www. bbc.com/sport/football/38365293

Leitner, H. (2012). Spaces of encounters: Immigration, race, class, and the politics of belonging in small-town America. Annals of the Association of American Geographers, 102(4), 828-846.

Lofland, L. H. (1989). Social life in the public realm: A review. Journal of Contemporary Ethnography, 17(4), 453-482.

Loopmans, M. (2002). Sociaal kapitaal, territorialiteit en ontmoetingsplaatsen: Lessen uit een interculturele vergelijking. Cultuur en Migratie, 19(2), 9-32. 
Loopmans, M. (2008). Relevance, gentrification and the development of a new hegemony on urban policies in Antwerp, Belgium. Urban Studies, 45(12), 2499-2519.

Mayblin, L., Valentine, G., Kossak, F., \& Schneider, T. (2015). Experimenting with spaces of encounter: Creative interventions to develop meaningful contact. Geoforum, 63, 67-80.

McPherson, M., Smith-Lovin, L., \& Cook, J. M. (2001). Birds of a feather: Homophily in social networks. Annual Review of Sociology, 27(1), 415-444.

Nichols, G., Tacon, R., \& Muir, A. (2013). Sports clubs' volunteers: Bonding in or bridging out? Sociology, 47(2), 350-367.

Oosterlynck, S., Schuermans, N., \& Loopmans, M. (2017). Beyond social capital: Place, diversity and solidarity. In S. Oosterlynck, N. Schuermans, \& M. Loopmans (Eds.), Place, diversity and solidarity (pp. 1-19). London: Routlegde.

Parsons, T. (1953). Some comments on the state of the general theory of action. American Sociological Review, 18(6), 618-631.

Parsons, T. (1990). Prolegomena to a theory of social institutions. American Sociological Review, 55(3), 319333.

Pettigrew, T. F., \& Tropp, L. R. (2006). A meta-analytic test of intergroup contact theory. Journal of Personality and Social Psychology, 90, 751-783.

Pettigrew, T. F., Tropp, L. R., Wagner, U., \& Christ, O. (2011). Recent advances in intergroup contact theory. International Journal of Intercultural Relations, 35, 271-280.

Piekut, A., \& Valentine, G. (2017). Spaces of encounter and attitudes towards difference: A comparative study of two European cities. Social Science Research, 62, 175-188.

Sampson, R. (2006). Collective efficacy theory: Lessons learned and directions for future inquiry. In F. Cullen, J. Wright, \& K. Blevins (Eds.), Taking stock: The status of criminological theory (pp. 149-167). New Brunswick \& London: Transaction Publishers.

Schug, J., \& Lu, P. S. (2015). To affinity and beyond! How our preference to be among similar people interacts with our social ecology. The Inquisitive Mind, 26.

Scott, W. R. (2013). Institutions and organizations: Ideas, interests, and identities. Los Angeles: Sage Publications.

Social Exclusion Unit (2001). Preventing Social Exclusion. Retrieved from www.housing.infoxchange.net.au

Spaaij, R. (2012). Building social and cultural capital among young people in disadvantaged communities: Lessons from a Brazilian sport-based intervention program. Sport, Education and Society, 17(1), 77-95.

Spijkers, F.E. (2019). How do we live together in diversity? A place-based perspective on the role of contact and professionals in fostering intercultural relations. PhD Thesis (KU Leuven).

Spijkers, F. E., \& Loopmans, M. (2018). Meaningful intercultural contact: How different places pave the way for learning to live together in diversity. Social and Cultural Geography, 1-21.

Spijkers, F., \& Moris, M. (2015) Rapport retrospectieve case studie City Pirates-Diegem Workingpaper. Retrieved from www.solidariteitdiversiteit.be.

Spijkers, F. \& Moris, M. (2016) Rapport retrospectieve casestudie: City pirates. [onderzoeksrapport]. Unpublished working paper: http://solidariteitdiversiteit.be/praktijkenbank.php?case $=10$.

Stad Antwerpen (2019). Rapport demografie: Stad Antwerpen, Stad in Cijfers [Demography report: Antwerp City, City in numbers]. Retrieved from https://stadincijfers.antwerpen.be/databank/Report?id= demografie parents\&input geo=antwerpen 1

Stein, R. M., Post, S. S., \& Rinden, A. L. (2000). Reconciling context and contact effects on racial attitudes. Political Research Quarterly, 53(2), 285-303.

Tasa, K., Taggar, S., \& Seijts, G. (2007). The development of collective efficacy in teams: A multi-level and longitudinal perspective. Journal of Applied Psychology, 92(1), 17-27.

Tolbert, P. S., \& Zucker, L. G. (1999). The institutionalization of institutional theory. Thousand Oaks: Studying Organization. Theory \& Method. London.

Tonts, M. (2005). Competitive sport and social capital in rural Australia. Journal of Rural Studies, 21(2), 139149.

Valentine, G. (2008). Living with difference: Reflections on geographies of encounter. Progress in Human Geography, 32(3), 323-337.

Wiesemann, L. (2012). Public spaces, social interaction and the negotiation of difference. MMG Working Paper, 12-08, 1-26.

Publisher's Note Springer Nature remains neutral with regard to jurisdictional claims in published maps and institutional affiliations. 